\title{
Shortening the induction delivery interval with prostaglandins: a randomized controlled trial of solo or in combination
}

\author{
Prostaglandinler ile indüksiyon-doğum aralığının kısaltılması: tek başına veya \\ kombine olguların randomize kontrollü karşılaştırılması
}

\author{
Rajiv Mahendru, Shweta Yadav \\ Department of Obstetrics and Gynecology, Mmimsr, Mullana, Ambala, India
}

\section{Abstract}

Objective: To compare the efficacy and safety of misoprostol alone with dinoprostone followed by misoprostol, all inserted intravaginally in induction of labor at term and the obstetrical outcome.

Material and Methods: A pilot study comprising 111 primigravidae, $>37$ gestational weeks with singleton pregnancy in cephalic presentation having an unfavorable Bishop score admitted for labor induction, were considered and randomly allocated into two groups. In group I $(n=55)$ with intravaginal $25 \mathrm{mcg}$ misoprostol 4 hourly (six doses at the most) and and group II $(\mathrm{n}=56)$, with dinoprostone $0.5 \mathrm{mg}$ followed eight hours later by $25 \mathrm{mcg}$ misoprostol induction to vaginal delivery time was found to be significantly different, being $14.8 \mathrm{~h}$ in groupand shorter in group-II with a mean of $11.6 \mathrm{~h}$. Vaginal delivery rates within $12 \mathrm{~h}$ (groups-I and -II: $47.2 \%$, as compared to $60.7 \%$, respectively) were found to be higher with dinoprostone-misoprostol induction, as well as vaginal delivery rates in $24 \mathrm{~h}, 80.0 \%$ and $91.1 \%$. The need for oxytocin augmentation was more frequent in the misoprostol than in the dinoprostone-misoprostol group, (61.8\%, and 39.3\%), and all these observations were statistically significant. Abnormal foetal heart rate pattern occurred more frequently $(18.2 \%)$ in group-I in contrast to $5.3 \%$ in group-II, as was the incidence rate of $(18.2 \%)$ who had passage of meconium in group-I, this rate being significantly different from group-II having meconium passage in 3 cases, a rate of $5.3 \%$.

Conclusion: Using dinoprostone followed by vaginal misoprostol is safe and effective for induction of labor with less need for oxytocin augmentation and shorter induction delivery interval.

(J Turkish-German Gynecol Assoc 2011; 12: 80-5)

Key words: Labor induction, prostaglandin, intravaginal

Received: 8 December, 2010

Accepted: 27 March, 2011
Özet

Amaç: Termde doğumun indüklenmesinde intravajinal olarak kullanılan tek başına misoprostol ile misoprostolün izlediği dinoprostonun etkililik ve güvenliliklerini ve obstetrik sonucu klyaslamak.

Gereç ve Yöntemler: >37 gebelik haftasında, sefalik prezentasyonda tekli gebeliği olan ve uygun olmayan Bishop skoru olup doğum indüksiyonu için başvuran 111 ilk gebeliği içeren bir pilot çalışma düşünüldü ve randomize olarak iki gruba ayrıldı. İntravajinal 4 saatte bir (en fazla altı doz) $25 \mathrm{mcg}$ misoprostol alan grup I $(n=55)$ ve $0.5 \mathrm{mg}$ dinoproston ve takiben sekiz saat sonra $25 \mathrm{mcg}$ mizoprostol alan grup II $(n=56)$ 'de vajinal doğum indüksiyon süresi anlamlı olarak farklı bulundu; grup I'de 14.8 saat, grup II'de ortalama 11.6 saat ile daha kısa olarak. 12 saat içinde vajinal doğum oranları (grup I ve II'de sırasıyla \%47.2'ye kıyasla \%60.7) dinoproston-misoprostol indüksiyonu ile daha yüksek bulundu; 24 saatteki vajinal doğum oranları da sırastyla $\% 80.0$ ve $\% 91.1$ idi. Oksitosin ilavesi gereksinimi misoprostolde dinoproston-misoprostol grubundan daha sıktı (\%61.8 ve \%39.3) ve bütün bu gözlemler istatistiksel olarak anlamlıydı. Anormal fötal kalp hızı paterni grup-I'de grup II'ye kıyasla daha sıklıkla görüldü (sırasıyla $\% 18.2$ ve \%5.3); benzer sekilde grup I'de mekonyum pasajı olanların insindans hızı (\%18.2), 3 vakada mekonyum pasajı olan grup II'den (\%5.3) anlamlı olarak farklı idi.

Sonuç: Vajinal misoprostol uygulamasının takip ettiği dinoproston kullanımı; oksitosin ilavesine daha az gerek duyulması ve daha kısa indüksiyon-doğum aralığı ile doğumun indüksiyonu için güvenilir ve etkilidir. (J Turkish-German Gynecol Assoc 2011; 12: 80-5)

Anahtar kelimeler: Doğum indüksiyonu, prostaglandin, intravajinal

Geliş Tarihi: 08 Aralık 2010

Kabul Tarihi: 27 Mart 2011

\section{Introduction}

Induction of labor is intended to achieve vaginal delivery by stimulating uterine contractions before its spontaneous onset, and is commonly performed in clinical practice. Generally, it is considered as a therapeutic option when the benefits of expeditious delivery outweigh the risks of continuing the pregnancy (1). Methods of induction of labor include administration of oxytocin, prostaglandin analogues and smooth muscle stimulants such as herbs or castor oil replacing the age-old mechanical methods such as digital stretching of the cervix and sweeping of the membranes, hygroscopic cervical dilators, extra-amniotic balloon catheters, artificial rupture of membranes and nipple stimulation (2).

Prostaglandins have been in use for cervical ripening and induction of labour since the 1970s and have been shown to be of benefit to reduce the need of caesarean section when the cervix is unfavorable (3). The goal of administration of prostaglandins in the process of induction of labour is to achieve cervical ripening before the onset of contractions (4).

Prostaglandin analogues, dinoprostone $\left(\mathrm{PGE}_{2}\right)$ and misoprostol $\left(\mathrm{PGE}_{1}\right)$, are widely used in induction of labor practice for ripening the cervix and stimulating uterine contractions in order to achieve vaginal delivery (5). Prostaglandin $\mathrm{E}_{2}$ has now become 
the drug of choice in well-resourced settings for cervical ripening and induction of labor, but it is expensive, unstable and requires refrigerated storage. The advent of misoprostol was considered as a revolution in the field of labour induction, but concerns exist regarding an increased incidence of fetal distress (6), meconium-stained liquor and hyperstimulation (7).

This study, probably the first of its kind, was undertaken to compare the efficacy of vaginal misoprostol alone with dinoprostone followed by misoprostol introduced vaginally for third trimester cervical ripening and induction of labour.

\section{Material and Methods}

A study based on 111 primigravidae, $\geq 37$ gestational weeks with singleton fetus in cephalic presentation admitted for labor induction, was conducted during the period between $19^{\text {th }}$ Nov. 2009 to $5^{\text {th }}$ Jun. 2010 in the Maharishi Markendeshwar Institute of Medical Sciences and Research, Mullana, (Ambala, India).

The institutional ethical committee approved the project and written informed consent was obtainedfrom each participant. Being a pilot study, sample size calculation was not required.

Those included were healthy primigravida patients aged 20-30 years with a singleton fetus in cephalic presentation $\geq 37$ weeks, having average adequate gynaecoid pelvis and no clinical evidence of cephalo- pelvic disproportion. Other criteria for eligibility included a relaxed uterus, Bishop score $\leq 4$, reactive non-stress test, estimated fetal weight between 25003500 grams. Exclusion criteria considered were women with a previously scarred uterus, poor fetal surveillance scores, contraindications for the application of prostaglandins (asthma, glaucoma, clinical evidence of cardiopulmonary, hepatic or renal disease), antepartum haemorrhage, significant maternal and fetal compromise, active genital herpes simplex infection or those who failed to supply the written informed consent.

One hundred and forty two women were enrolled for the study but 31 of these did not meet the inclusion criteria (non-cephalic presentation $n=9$, favorable Bishop score $n=8$, non-compliance to written informed consent $n=7$, severe intra-uterine growth restriction $n=3$, major degree placenta praevia $n=2$, signs of fetal compromise $n=2$ ). Allocation of the rest of the 111 patients was done into two groups by using a randomized table of numbers. Index cards with the random assignment were prepared and placed in sealed envelopes, a researcher who was blinded to the baseline examination findings opened the envelope, at the time of induction of labor, and the proceedings were done according to the group assignment.

All the patients were admitted to the hospital from the beginning of the labor induction process and were subjected to detailed history taking, a complete physical examination and investigations, including a complete haemogram, random blood sugar, blood urea, serum creatinine (as a preparation for emergent cesarean section, if needed), an obstetric ultrasonography and a cardiotocography.

The baby's condition was assessed by clinical assessment of growth and amniotic fluid volume and also the mother's report of fetal movements. Prior to starting the induction process, the woman was carefully assessed for evidence of fetal compromise by electronic fetal heart rate monitoring for 30 minutes. The nonstress test (NST) to ensure the well-being of the fetus was performed for each patient at the time of recruitment and admission to the hospital and one hour before the application of the prostaglandin. After the reassessment of the cervical Bishop score, either
25 mcg misoprostol, or $0.5 \mathrm{mg}$ dinoprostone was administered in the posterior vaginal fornix as per the group allocation.

As depicted in Figure 1, two groups were assigned: group-I $(n=55)$ where $25 \mathrm{mcg}$ misoprostol was used intravaginally every 4 hours (six doses at the most) and group-II $(n=56)$ in whom the process was initiated with intravaginal dinoprostone $0.5 \mathrm{mg}$ followed eight hours later by $25 \mathrm{mcg}$ misoprostol inserted in the same way every 4 hours (four doses maximum). In group-I, $25 \mathrm{mcg}$ misoprostol tablet (available of late) was inserted in the posterior fornix following the vaginal examination; thereafter the patients were continuously monitored for one hour and then allowed to ambulate. Monitoring was continued intermittently until the next scheduled dose after 4 hours, unless the membranes ruptured or fetal heart rate tracing was not reactive. A maximum of six doses were given, until an adequate contraction pattern (three or more contractions within $10 \mathrm{~min}$ ), cervical ripening (Bishop score $\geq 7$ or dilation $\geq 3 \mathrm{~cm}$ ), spontaneous membrane rupture occurred or $24 \mathrm{~h}$ had elapsed. Artificial rupture of membranes was generally performed when it was clinically safe-cervix was $80 \%$ effaced or $3 \mathrm{~cm}$ dilated or when dilation was $\geq 4 \mathrm{~cm}$ regardless of the effacement.

Once started, the woman was monitored closely for fetal heart rate (FHR) and uterine activity, as well as the mother's vital signs were constantly monitored for $60 \mathrm{~min}$ after each dose of misoprostol, and every $30 \mathrm{~min}$ from the onset of uterine contractions. Electronic fetal monitoring was used from the time at which regular contractions commenced after every 3 min or more.

At the time of each planned misoprostol dose, the woman was clinically reassessed. If there were $0-2$ contractions every 10 minutes, then a further dose of misoprostol was given and if there were 3 or more uterine contractions in 10 minutes, then clinical judgement was used to assess the best way of continuing the induction to achieve optimal contractions (3 strong contractions in 10 minutes). Wherever required, intravenous oxytocin infusion was commenced, but not less than 4 hours after the last dose of vaginal misoprostol.

In group-II patients, $0.5 \mathrm{mg}$ of dinoprostone in gel form was instilled intravaginally in the posterior fornix and continuous monitoring was done for one hour before allowing the patient to ambulate. Eight hours later, misoprostol protocol was started/ followed in the same manner as in group-I, the difference being the number of doses reduced to four. In both the groups: oxytocin infusion was started following spontaneous rupture of membranes without an ensuing adequate contraction pattern or no change in cervical dilatation for $2 \mathrm{~h}$ at $\geq 4 \mathrm{~cm}$. Oxytocin was administered according to the protocol: initiated at $4 \mathrm{mU} / \mathrm{min}$ and increased $4 \mathrm{mU} / \mathrm{min}$ every $30 \mathrm{~min}$ to a maximum of $16 \mathrm{mU} / \mathrm{min}$ until adequate effective uterine contractions were established. Once the patient was in active labor, further monitoring and conduction of delivery was done by a consultant obstetrician. If the Bishop score was unchanged and inadequate uterine contractions persisted $4 \mathrm{~h}$ after the last dose of misoprostol, the case was labelled as a failed induction and caesarean section was performed. Neonates were evaluated for Apgar scores.

To observe uniformity, right medio-lateral episiotomy was employed at the instance of crowning of the vertex in all the cases of vaginal delivery and the placenta was delivered by modified Brandt- Andrew's technique (controlled cord traction) at the clinical confirmation of its separation following delivery of the baby.

The vaginal administration of prostaglandins was performed by one of the resident doctors on duty, who was not involved 


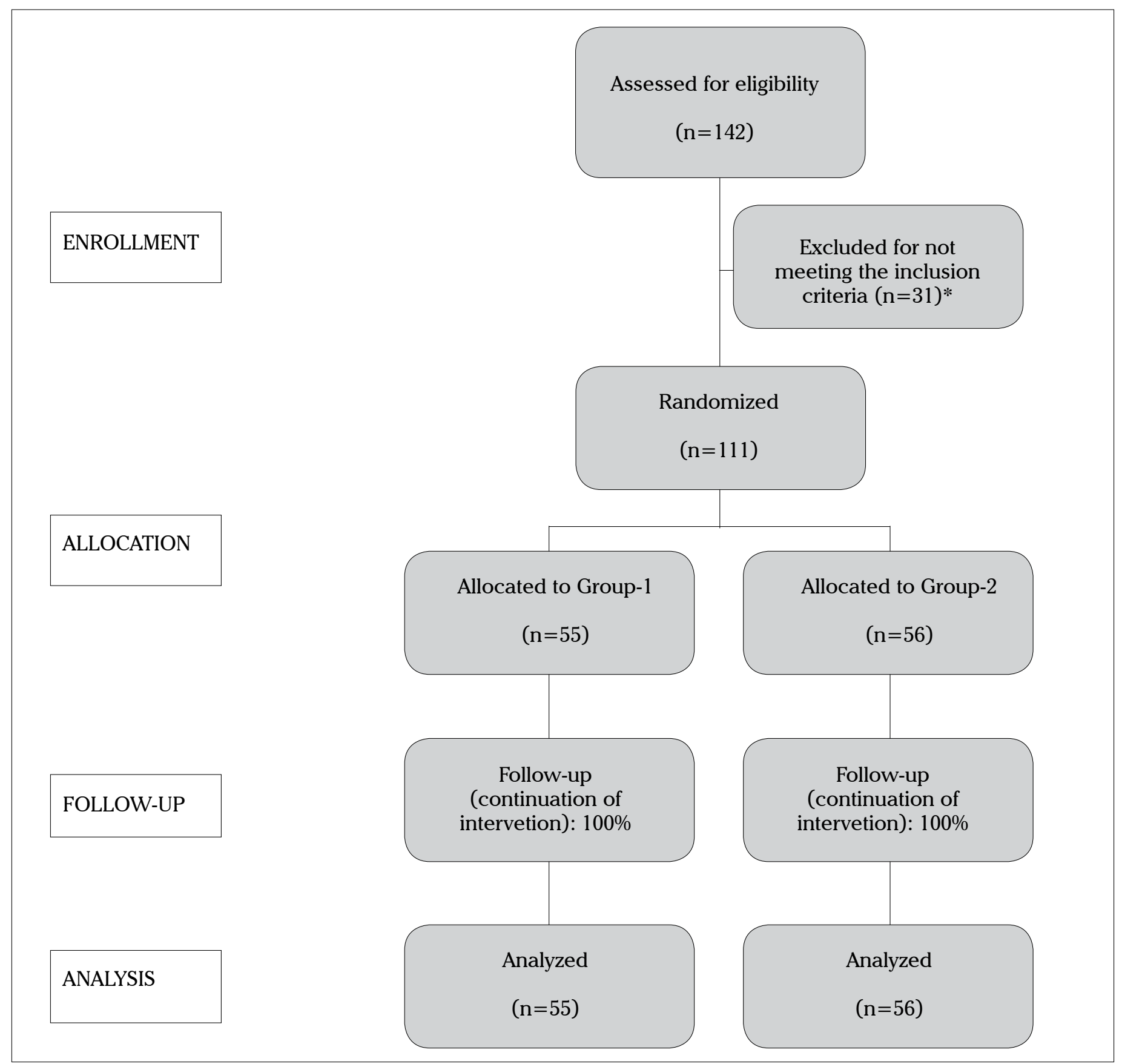

Figure 1. The CONSORT Flow Diagram showing the progress of participants at each stage of the study *(non-cephalic presentation $n=9$, favorable Bishop score $n=8$, non-compliance to written informed consent $n=7$, severe intra-uterine growth restriction $n=3$, major degree placenta praevia $n=2$, signs of fetal compromise $n=2$ )

in managing these women in labor or delivery. The study was blind, since the patients were not aware of which type of medication was used, and the deliveries were then performed by a consultant obstetrician blinded to the induction regimen utilized. Uterine tachysystole was defined as more than five contractions per 10 minutes for at least 20 minutes, uterine hypersystole/hypertonus as when one contraction lasted more than 2 minutes and hyperstimulation syndrome as the presence of non-reassuring FHR tracing combined with either tachysystole or hypertonus (8). Non-reassuring FHR patterns were defined as persistent or recurring episodes of severe variable decelerations, late decelerations, prolonged fetal bradycardia or a combination of decreased beat-to-beat variability and a decelerative pattern (9). Tocolytic agents were kept on hand to manage such eventualities where possible and were to be given subcutaneous terbutaline $250 \mu \mathrm{g}$ as a single dose.

All the observations were given consideration in both the groups. The data were tabulated and analyzed. Summary statistics such as mean, standard deviation were estimated. Chisquare and Fisher's exact tests were used for categorical data. 
For continuous data such as age, weight, student's t-test was utilised. The significance was seen after applying log transformation and statistical significance was set at $\mathrm{p}<0.05$.

\section{Observations}

The outcome measures considered were both obstetrical and neonatal. The primary outcome measures were time from induction to delivery and incidence of vaginal delivery within 12 and 24 hours and the Caesarean Section rate, the incidence of uterine tachysystole, abnormal (FHR) tracings. The secondary outcomes were the need for oxytocin augmentation, the incidence of meconium stained amniotic fluid, maternal morbidity, neonatal Apgar scores and the admission to neonatal intensive care within 24 hours.

As depicted in Table 1, the two groups were comparable in terms of patient age, weight, height and indication for induction (post-date pregnancy $40.0 \%$ and $39.3 \%$, social $23.6 \%$ and $25.0 \%$, oligohydramnios $16.4 \%$ and $14.3 \%$, pregnancy induced hypertension $20.0 \%$ and $21.4 \%$ in group-I and group-II, respectively). Gestational age and the preinduction Bishop score in the misoprostol group-I were also comparable to the dinoprostone and misoprostol combination group-II.

There was a significant change in the Bishop score in the two groups after eight hours of initiating the process of induction, that is, after two doses of $25 \mathrm{mcg}$ misoprostol in group-I and after $0.5 \mathrm{mg}$ of dinoprostone in group-II, being 5.3 (range 4-7) compared to 7.4 (range $6-8$ ), meaning thereby that the cervix became favourable in all cases in group-II.

The induction-delivery interval in the two groups was significantly shorter in group-II, with even less need for a second or third dose in the said group. A salient observation to be mentioned is that five of the patients in group-II had onset of active labor with dinoprostone alone, obviating the need for any misoprostol in these subjects. With the dinoprostone-misoprostol combination, more women delivered within 12 hours of induction $(47.2 \%, \mathrm{n}=26$ vs $60.7 \%, \mathrm{n}=34)$ and this difference even persisted at $24 \mathrm{~h}(80.0 \%, \mathrm{n}=44$ in group-I, in significant contrast to $91.1 \%, \mathrm{n}=51$ in group-II). Moreover, the need for oxytocin augmentation in labor was also different, being remarkably reduced in group-II. In addition, spontaneous rupture of the membranes occurred with almost the same frequency in both groups. Other significant findings, though adverse in nature, were observed more frequently in group-I: abnormal uterine actions-uterine tachysystole $(10.9 \%, \mathrm{n}=6$ vs $3.6 \%, \mathrm{n}=2)$, uterine hyperstimulation ( $1.8 \%$ vs $0.0 \%)$, and meconium stained amniotic fluid $(18.2 \%, \mathrm{n}=10$ vs $5.3 \%, \mathrm{n}=3)$ as did abnormal heart rate tracing $(18.2 \%, n=10$ vs $5.3 \%, n=3$ ) (Table 2 ).

In both the groups, although the majority of women had a vaginal delivery (more in group-II), there was a statistically significant difference between the two groups with regard to the Caesarean Section rate, being $20.0 \%, n=11$ in group-I as compared to $8.9 \%, \mathrm{n}=5$ in group-II (Table 3 ). There were no uterine ruptures or other major maternal complications resulting from the use of either of the prostaglandins- alone or in synergy. There was one episiotomy wound infection in group-I, one woman in each group had delayed discharge from the hospital due to puerperal pyrexia (which eventually turned out to be due to an urinary tract infection) and two women in the misoprostol group required bimanual uterine compression due to postpartum bleeding which did not amount to alarming proportions.
Table 1. Patient profile and indications of induction of labor

\begin{tabular}{|c|c|c|c|}
\hline & $\begin{array}{c}\text { Group-I } \\
(n=55) \\
\text { Mean } \\
\text { (Range) }\end{array}$ & $\begin{array}{c}\text { Group-II } \\
(\mathrm{n}=56) \\
\text { Mean } \\
\text { (Range) }\end{array}$ & $\begin{array}{c}\mathbf{p} \\
\text { Value }\end{array}$ \\
\hline \multicolumn{4}{|l|}{ Patient Profile } \\
\hline Age (years) & $\begin{array}{c}21.6 \\
(20.2-26.7)\end{array}$ & $\begin{array}{c}22.3 \\
(20.0-26.9)\end{array}$ & $>0.05$ \\
\hline Weight (kg) & $\begin{array}{c}58.41 \\
(43.4-76.4)\end{array}$ & $\begin{array}{c}57.92 \\
(42.5-77.0)\end{array}$ & $>0.05$ \\
\hline Height $(\mathrm{cm})$ & $\begin{array}{c}150.3 \\
(148.2-154.2)\end{array}$ & $\begin{array}{c}150.8 \\
(147.6-153.8)\end{array}$ & $>0.05$ \\
\hline Gestational age (wks) & $\begin{array}{c}38.2 \\
(37.2-40.4) \\
\end{array}$ & $\begin{array}{c}38.2 \\
(37.4-40.5) \\
\end{array}$ & \\
\hline Bishop score at IOL & $3.3(2-4)$ & $3.3(2-4)$ & \\
\hline Indications of Iol* & n (\%) & n (\%) & \\
\hline Post-date pregnancy & $22(40.0 \%)$ & $22(39.3 \%)$ & \\
\hline Social & $13(23.6 \%)$ & $14(25.0 \%)$ & \\
\hline Oligohydramnios & $9(16.4 \%)$ & $8(14.3 \%)$ & \\
\hline $\begin{array}{l}\text { Term pregnancy with } \\
\text { Pregnancy Induced } \\
\text { Hypertension }\end{array}$ & $11(20.0 \%)$ & $12(21.4 \%)$ & \\
\hline
\end{tabular}

More neonates in group-I had first minute Apgar scores lower than 7 , or needed neonatal resuscitation, but none of the babies had birth asphyxia. Meconium aspiration syndrome was not noticed in any of the neonates. (Table 4). There was a difference in the number of neonates admitted to the intensive care within 24 hours after delivery between the misoprostol and dinoprostone-misoprostol groups, being $5.4 \%(n=3)$ vs $1.8(n=1)$.

In group-I, a salient adverse eventuality was confronted in the form of an unexplained stillbirth in a 26-year-old woman at 40 weeks of gestation after having received two doses of misoprostol. The sequence was that, for one hour of receiving the said dose of misoprostol, she continued to have normal FHR patterns with regular contractions of the uterus, but after the next half hour, there was no cardiac activity. Artificial rupture of the membranes was performed, which drained liquor clear of meconium and the vaginal delivery occurred within the next four hours and the baby had no cardio-respiratory activity. Gross examination of the newborn did not reveal any abnormality, but consent for autopsy could not be procured.

\section{Discussion}

Nowadays, induction of labor is more widely used than ever before $(10,11)$ and, according to Ventura et al. (12) the overall rate of induction of labor in the United States has more than doubled in a span of eight years. Recent studies have shown that this increase is mainly due to a rise in inductions for marginal or elective reasons. The most potent and acceptable methods of induction are the prostaglandins (1).

Misoprostol is a methyl ester of $\mathrm{PGE}_{1}$ additionally methylated at C-16 and can be used orally, vaginally and sublingually (13). When introduced vaginally, absorbed serum levels are more prolonged (14). There are many studies which investigate the utilization of misoprostol in labor induction, but concerns still 
exist regarding the increased incidence of fetal distress (15), meconium staining and hyperstimulation.

$\mathrm{PGE}_{2}$ is an acceptable method of cervical ripening $(15,16)$ and is commercially available as a gel and vaginal insert, both of which are approved by the FDA for cervical ripening in women at or near term and both have been reported to increase the probability of successful initial induction by ripening the cervix (17). Dosage schedules used range from 6-12 hours (15, 18-20). In the current study we used eight hours for uniformity to coincide with the first two doses of misoprostol.

Lyons et al. (21) have shown in term pregnant rats that a

Table 2. Obstetrical outcome

\begin{tabular}{|c|c|c|c|}
\hline $\begin{array}{l}\text { Obstetrical } \\
\text { Outcome }\end{array}$ & $\begin{array}{l}\text { Group-I } \\
(n=55)\end{array}$ & $\begin{array}{l}\text { Group-II } \\
(n=56)\end{array}$ & $\begin{array}{c}\text { Statistical } \\
\text { significance }\end{array}$ \\
\hline $\begin{array}{l}\text { Change in Bishop } \\
\text { score after eight } \\
\text { hours* Mean (Range) }\end{array}$ & $5.3(4-7)$ & $7.4(6-8)$ & $\mathrm{p}<0.05$ \\
\hline $\begin{array}{l}\text { Time from induction } \\
\text { to delivery (h) } \\
\text { Mean (Range) }\end{array}$ & $\begin{array}{c}14.8 \\
(9.8-22.4)\end{array}$ & $\begin{array}{c}11.6 \\
(8.8-19.2)\end{array}$ & $\mathrm{p}<0.05$ \\
\hline \multicolumn{4}{|l|}{ Delivery n (\%) } \\
\hline$<12 \mathrm{~h}$ & $26(47.2 \%)$ & $34(60.7 \%)$ & $\mathrm{p}<0.05$ \\
\hline$<24 \mathrm{~h}$ & $44(80.0 \%)$ & $51(91.1 \%)$ & \\
\hline $\begin{array}{l}\text { Required oxytocin } \\
\text { augmentation } \mathrm{n}(\%)\end{array}$ & $34(61.8 \%)$ & $22(39.3 \%)$ & $\mathrm{p}<0.05$ \\
\hline $\begin{array}{l}\text { Spontaneous rupture } \\
\text { of membranes n (\%) }\end{array}$ & $19(34.5 \%)$ & $18(32.1 \%)$ & NS \\
\hline $\begin{array}{l}\text { Meconium stained } \\
\text { AF n (\%) }\end{array}$ & $10(18.2 \%)$ & $3(5.3 \%)$ & $\mathrm{p}<0.05$ \\
\hline \multicolumn{4}{|l|}{ Adverse Findings n (\%) } \\
\hline Abnormal FHR & $10(18.2 \%)$ & $3(5.3 \%)$ & \multirow{3}{*}{$\mathrm{p}<0.05$} \\
\hline Uterine Tachysystole & $6(10.9 \%)$ & $2(3.6 \%)$ & \\
\hline $\begin{array}{l}\text { Uterine } \\
\text { Hyperstimulation }\end{array}$ & $1(1.8 \%)$ & $-(0.0 \%)$ & \\
\hline $\begin{array}{l}\mathrm{FHR}=\text { Fetal heart rate } \\
\mathrm{AF}=\text { Amniotic fluid } \mathrm{NS}=\mathrm{n}\end{array}$ & nificant & & \\
\hline
\end{tabular}

Table 3. Mode of delivery

\begin{tabular}{|c|c|c|c|}
\hline Mode of delivery & $\begin{array}{c}\text { Group-I } \\
(n=55) \\
n(\%)\end{array}$ & $\begin{array}{c}\text { Group-II } \\
(\mathrm{n}=56) \\
\mathrm{n}(\%)\end{array}$ & $\begin{array}{c}\text { Statistical } \\
\text { significance }\end{array}$ \\
\hline Vaginal & $44(80.0 \%)$ & $51(91.1 \%)$ & \multirow{3}{*}{$\mathrm{p}<0.05$} \\
\hline Spontaneous & $30(68.2 \%)$ & $44(86.3 \%)$ & \\
\hline Vacuum assisted & $14(31.8 \%)$ & $7(13.7 \%)$ & \\
\hline Caesarean section & $11(20.0 \%)$ & $5(8.9 \%)$ & \multirow{5}{*}{$\mathrm{p}<0.05$} \\
\hline Nonreassuring FHR & $5(9.0 \%)$ & $2(3.6 \%)$ & \\
\hline Failed induction & $4(7.4 \%)$ & $2(3.6 \%)$ & \\
\hline Lack of labor & $2(3.6 \%)$ & $1(1.8 \%)$ & \\
\hline Progress* & & & \\
\hline $\begin{array}{l}\mathrm{FHR}=\text { Fetal heart rate } \\
* \text { No progress in dilatati } \\
\text { active phase of establis }\end{array}$ & $\begin{array}{l}\text { desce } \\
\text { bor }\end{array}$ & 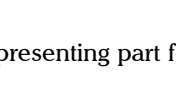 & in \\
\hline
\end{tabular}

higher dose of misoprostol is needed to induce PGE2 secretion in the cervix than in the myometrium, and furthermore that EP3 receptors (prostaglandin E2 receptors) are differentially expressed in the myometrium (increased) than in the cervix (unaltered) in response to misoprostol. The above findings indicate that misoprostol not only acts better on the myometrium than on the cervix, but an even higher dose is needed in order to ripen the cervix. Thus, it seems reasonable that initiating the labor induction process by cervical ripening with dinoprostone followed by repeated small misoprostol doses should reduce the risk of asynchrony between a well or even hyper-stimulated uterus and a still not efficiently ripened cervix.

Taking this explanation into consideration, the current study has been conducted and as per review of the literature, this appears to be the only comparison, up to date, between misoprostol alone and combination of dinoprostone followed by misoprostol in such well-homogenized groups. All of the women were nulliparous with intact membranes and at term, with no antenatal complications and all had an unfavorable cervix. In these carefully selected patients, dinoprostone was used initially to ripen the unfavorable cervix, followed by misoprostol to have a synergistic effect on the progress of labor. This combination, in the schedule mentioned, not only shortened the time between induction and delivery, but was also significantly more effective than misoprostol alone. The positive point was that this result was achieved with a comparatively low caesarean rate, although in the recent large meta-analysis (22) published by the Cochrane Library, the caesarean section rates were inconsistent. Even though misoprostol improves the kinetics of labor during induction in a more efficient way than dinoprostone used alone, concerns persist with respect to intrapartum fetal wellbeing. In order to avoid uterine hyperstimulation and abnormal FHR tracings, this study on the combination of dinoprostone and misoprostol resulted in a lower incidence of these complications. Our findings, in accordance with the previous Cochrane metanalysis, showed that, with only misoprostol, there was an increased probability of meconium staining of amniotic fluid as well as of uterine tachysystole and of abnormal FHR tracings. If neonatal outcomes such as neonatal resuscitation, low Apgar score in the first minute and admittance to the neonatal unit within the first 24 hours are taken into account, misoprostol may increase these complications in labor.

\section{Table 4. Neonatal outcome}

\begin{tabular}{|l|c|c|c|}
\hline Neonatal Outcome & $\begin{array}{c}\text { Group-I } \\
(\mathbf{n = 5 5 )}\end{array}$ & $\begin{array}{c}\text { Group-II } \\
(\mathbf{n = 5 6 )}\end{array}$ & $\begin{array}{c}\text { Statistical } \\
\text { significance }\end{array}$ \\
\hline $\begin{array}{l}\text { Birth weight (g) } \\
\text { Mean (Range) }\end{array}$ & $\begin{array}{c}28 \\
(2520-3320)\end{array}$ & $\begin{array}{c}291060 \\
(2500-3480)\end{array}$ & \\
\hline Apgar score $<7$ & $\mathrm{n}(\%)$ & $\mathrm{n}(\%)$ & \\
\hline 1 min & $7(12.7 \%)$ & $2(3.6 \%)$ & \\
\hline 5 min & $1(1.8 \%)$ & $-(0.0 \%)$ & \\
\hline Neonatal resuscitation & $7(12.7 \%)$ & $4(7.1 \%)$ & \\
\hline $\mathrm{O}_{2}$ Supplementation & 2 & 2 & \\
\hline Ambou ventilation & 4 & 2 & \\
\hline $\begin{array}{l}\text { Intubation in labor } \\
\text { room }\end{array}$ & 1 & - & \\
\hline Perinatal death & $1(1.8 \%)$ & $-(0.0 \%)$ & \\
\hline NICU admissions & $3(5.4 \%)$ & $1(1.8 \%)$ & \\
\hline
\end{tabular}


Attempting an explanation for the aforementioned side effects of misoprostol use, and taking into account other reports $(23,24)$, it appears that the increase in clinically relevant adverse effects is not only misoprostol related but it may be dose dependent. Misoprostol probably has a large inter-patient variability in terms of pharmacokinetics, but the more probable explanation could be that it may induce asynchrony between immature cervix effacement and uterine contractions. Based on these reviews and findings from the study under consideration, it is proposed that, in future, further randomized controlled studies be conducted to establish the regimen of dinoprostone followed by misoprostol in attempting to achieve priming of the cervix (with dinoprostone) before inducing effective uterine contractility (with subsequent misoprostol): this may reduce uterine hyperstimulation and neonatal complications. Merrell and coworkers (25) reported a series of 62 inductions of labor with vaginal misoprostol: there were two stillbirths, one apparently due to a tight nuchal cord, and one unexplained as reported in one of our cases. The exact cause of the stillbirth in this case remained unclear, thus emphasizing the need for continuous FHR monitoring during labor induction if regular uterine contractions persist (26). A significant observation worth mentioning is that five of the subjects delivered with dinoprostone only without the use of misoprostol.

According to Tan and Tay (27), dinoprostone improves the chances of successful ripening and shortens the interval from priming to induction, and priming to delivery. Combination with misoprostol reduces the need for repeated dinoprostone, thus cutting the cost. This combination may be more cost effective by not only shortening the period of hospital stay but also by reduced incidence of cesareans and neonatal resuscitation and the overall low incidence of adverse reactions in the mother and fetus.

\section{Conclusion}

Using dinoprostone for cervical priming followed by vaginal misoprostol not only hastened the progress of labor, with a greater percentage of women delivering vaginally and consequent reduction in caesarean section rate, but also reduced the adverse effects encountered with misoprostol when used alone, namely, tachysystole, uterine hyperstimulation and fetal heart abnormalities.

\section{Conflict of interest}

No conflict of interest was declared by the authors.

\section{References}

1. American College of Obstetricians and Gynecologists ACOG Practice Bulletin no217. Washington, DC: American College of Obstetricians and Gynecologists; Clinical Management guidelines for ObstetricianGynecologists. Number 10, November 1999: 603-12.

2. Mitri F, Hofmeyr G J, Van Gelderen C J. Meconium during labour: self-medication and other associations. South African Medical Journal 1987; 71: 431-3.

3. Kelly AJ, Kavanagh J, Thomas J. Vaginal prostaglandin (PGE2 and PGF2a) for induction of labour at term. Cochrane Database Syst Rev 2003; CD003101.

4. Boulvain M, Kelly A, Irion O. Intracervical prostaglandins for induction of labour. Cochrane Database Syst Rev 2008; CD006971.

5. Papanikolaou EG, Plachouras N, Drougia A, Andronikou S, Vlachou C, Stefos T, et al. Comparison of Misoprostol and Dinoprostone for elective induction of labour in nulliparous women at full term: A randomized prospective study. Reprod Biol Endocrinol 2004; 2: 70. [CrossRef]

6. Alfirevic Z, Faúndes A, Hofmeyr GJ, Safar P, Wing D. Misoprostol for induction of labor with a live fetus Weeks. International Journal of Gynecology and Obstetrics 2007;99: S194-7.

7. Nigam A, Madan M, Puri M, Agarwal S, Trivedi SS. Labour induction with 25 micrograms versus 50 micrograms intravaginal misoprostol in full term Pregnancies. Tropical Doctor 2010; 40: 53-5. [CrossRef]

8. Hofmeyr GJ, Gülmezoglu AM. Vaginal misoprostol for cervical ripening and induction of labour. Cochrane Database of Systematic Reviews 2003; Art. No: CD000941.

9. American College of Obstetricians and Gynecologists ACOG Practice Bulletin no207. Washington, DC: American College of Obstetricians and Gynecologists; 1995. Fetal heart rate patterns: monitoring, interpretation, and management.

10. Goffinet F, Humbert R, Clerson P, Philippe HJ, Breart G, Cabrol D. [National survey on the use of induced labor by obstetricians. Study Group on Induced Labor] J Gynecol Obstet Biol Reprod (Paris) 1999; 28: 319-29.

11. Rayburn WF, Zhang J. Rising rates of labor induction: present concerns and future strategies. Obstet Gynecol 2002; 100: 164-7. [CrossRef]

12. Ventura SJ, Martin JA, CurtinSC, Mathews TJ. Births: Final data for 1997. National Center for Health Statistics, National Vital Statistics Reports 1999; 47: 1-96.

13. Fuser D, Fernando M, Arias F. A randomized comparison between misoprostol and dinoprostone for cervical ripening and labour induction in patients with unfavourable cervix. Obstet Gynaecol 1997; 89: 581-5. [CrossRef]

14. Zieman M, Fong SK, Benowitz NL, Banskter D, Darney PD. Absorption kinetics of misoprostol with oral or vaginal administration. Obstetrics and Gynecology 1997; 90: 88-92. [CrossRef]

15. Papanikolaou EG, Plachouras N, Drougia A, Andronikou S, Vlachou C, Stefos T, et al. Comparison of misoprostol and dinoprostone for elective induction of labor in nulliparous female at full term: a randomized prospective study. Reprod Biol Endocrinol 2004; 2: 70. [CrossRef]

16. Krammer J, Williams MC, Sawai SK, O'Brien WF. Preinductioncervical ripening: randomized comparison of two methods. Obstet Gnecol 1995; 85: 641-4. [CrossRef]

17. Porto M. The unfavorable cervix: methods of cervical priming. Clin Obstet Gynecol 1989; 32: 262-8. [CrossRef]

18. Brindley BA, Sokol RJ. Induction and augmentation of labor : basis and methods for current practice. Obstet Gynecol Surv1998; 43: 730-43.

19. Sifakis S, Angelakis E, AvgoustinakisE, FragouliY, Mantas N, Koukoura O, et al. A rAndomized comparison between intravaginal misoprostol and prostaglandin E2 for labor induction. Arch Gynecol Obstet 2007; 275: 263-7.

20. Belfrage P, Smedvig E, Gjessing L, Eggebø TM, Okland I. A randomized prospective study of misoprostol and dinoproston for induction of labor.Acta Obstet Gynecol Scand 2000; 79: 1065-8.

21. Lyons C, Beharry K, Akmal Y, Attenello F, Nageotte MP. In vitro response of prostaglandin E2 receptor (EP3) in the term pregnant rat uterus and cervix to misoprostol. Prostaglandins Other Lipid Mediat 2003; 70: 317-21.

22. Hofmeyr GJ, Gulmezoglu AM. The Cochrane Library. Oxford: Update Software; 2002. Vaginal misoprostol for cervical ripening and induction of labour (Cochrane review).

23. Sanchez-Ramos L, Kaunitz AM, Wears RL, Delke I. Labor induction with $25 \mu \mathrm{g}$ versus $50 \mu \mathrm{g}$ intravaginal misoprostol: a systematic review. Obstet Gynecol 2002; 99: 145-55.

24. Blanchard K, Clark S, Winikoff B, Gaines G, Kabani G, Shannon C. Misoprostol for women's health: A Review. Obstet Gynecol 2002; 99: 316-22.

25. Merell DA, Koch MAT. Induction of labour with misoprostol in the second and third trimesters of pregnancy. South African Medical Journal 1995; 85: 1088-90.

26. American College of Obstetricians and Gynecologists. ACOG Practice Bulletin no10. Washington, DC: American College of Obstetricians and Gynecologists 1999. Induction of Labor.

27. Tan LK, Tay SK. Two dosing regimens for preinduction cervical priming with intravaginal dinoprostone pessary: a randomised clinical trial. Br J Obstet Gynaecol 1999; 106: 907-12. 